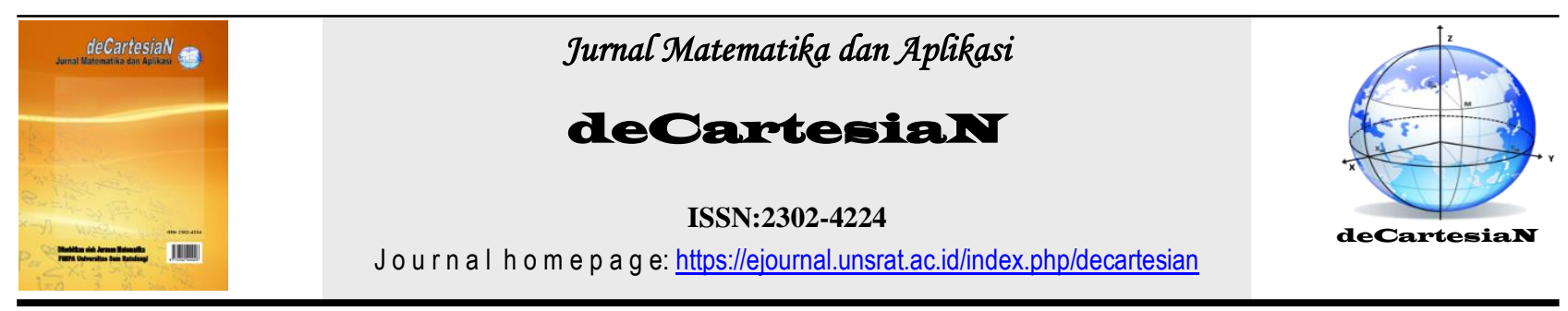

\title{
Model Sistem Antrian dengan Menggunakan Pola Kedatangan dan Pola Pelayanan Pemohon SIM di Satuan Penyelenggaraan Adminstrasi SIM Resort Kepolisian Manado
}

\author{
M. Safril Bahar ${ }^{1}$, Mans Lumiu Mananohas ${ }^{1}$, Chriestie E. J. C. Montolalu ${ }^{1 *}$ \\ ${ }^{1}$ Program Studi Matematika-Fakultas Matematika dan Ilmu Pengetahuan Alam-UNSRAT, Manado Indonesia \\ *Corresponding author: chriestelly@yahoo.com
}

\begin{abstract}
A B S T R A K
Antrian merupakan suatu keadaan di mana seorang harus menunggu gilirannya untuk mendapatkan pelayanan. Antrian disebabkan oleh sekelompok orang yang membutuhkan jasa pelayanan pada waktu bersamaan. Suatu proses kedatangan dalam suatu sistem antrian artinya menentukan distribusi probabilitas jumlah kedatangan untuk suatu periode waktu. Dalam hal ini, distribusi probabilitas Poisson menyediakan deskripsi yang cukup baik untuk suatu pola kedatangan. Sedangkan untuk Pola pelayanan ditentukan oleh waktu pelayanan yaitu waktu yang dibutuhkan untuk melayani pelanggan pada fasilitas pelayanan. Penelitian ini bertujuan untuk menerapkan sistem antrian dan mengurangi waktu tunggu di Satuan penyelenggaraan Adminstrasi SIM Resort Kepolisian Manado. Penelitian ini dilakukan di Satuan penyelenggaraan Adminstrasi SIM Resort Kepolisian Manado. Metode analisis yang digunakan adalah menggunakan pola kedatangan dan pola pelayanan. Dari hasil pembahasan yang telah dilakukan maka dapat disimpulkan bahwa sistem antrian pada SATPAS POLRESTA Manado memiliki tingkat kedatangan pemohon SIM sebesar 0.014 orang per menit. Waktu pelayanan pemohon SIM di loket I 1.979 menit rata-rata pemohon SIM dilayani, dan waktu pelayanan pemohon SIM di loket II 1.665 menit rata-rata pemohon SIM dilayani, namun waktu pelayanan pemohon SIM di loket III o.368 menit rata-rata pemohon SIM dilayani.
\end{abstract}

\author{
INFO ARTIKEL \\ Diterima $\quad: 18$ Januari 2018 \\ Diterima setelah revisi : 6 Februari 2018 \\ Tersedia online $\quad: 31$ Maret 2018
}

\section{Kata Kunci :}

Pola kedatangan,

Pola pelayanan,

Sistem Antrian,

SATPAS Manado

\section{PENDAHULUAN}

Satuan Penyelenggara Administrasi SIM (SATPAS) adalah pihak yang berwenang untuk menerbitkan Surat Ijin Mengemudi (SIM) bagi pengendara kendaraan bermotor.

Proses pembuatan SIM meliputi pendaftaran, ujian teori, ujian praktek, teskesehatan, registrasi, pembayaran, pengisian formulir, foto, sampai SIM tersebut jadi. Walaupun alurnya terlihat sederhana, namun proses pembuatan SIM tersebut terkadang memakan waktu cukup lama dan tidak jarang menimbulkan antrian yang membuat pemohon SIM menunggu cukup lama. Semakin banyak pengguna kendaraan bermotor, maka akan semakin banyak pemohon pembuatan SIM. Jumlah pemohon SIM yang datang tidak pasti dan cenderung lebih besar daripada jumlah sumber daya yang ada.

Hal ini dapat menimbulkan permasalahan yaitu terjadinya antrian (bottleneck) dan kesulitan untuk merencanakan alur proses pelayanan pembuatan SIM, serta kesulitan dalam mengatur kapasitas sumber daya di SATPAS. Untuk mencegah agar pembuatan SIM tidak memakan banyak waktu, biaya tunggu dan untuk tercipta sebuah model antrian adalah menggunakan cara, menganalisis sistem antrian.Penyedia pelayanan dapat mengusahakan agar dapat melayani pemohon SIM tersebutdengan baik tanpa harus menunggu lama.Salah satu cara untuk menganalisis masalah yang terjadi pada suatu antrian adalah dengan menerapkan aplikasi matematika teori antrian dimana analisis dapat dilakukan dengan mengadakan penelitian dimana antrian yang banyak memakan waktu.

Antrian merupakan suatu keadaan di mana seorang harus menunggu gilirannya untuk mendapatkan pelayanan. Antrian disebabkan oleh sekelompok orang yang membutuhkan jasa pelayanan pada waktu bersamaan. Dalam penelitian yang akan dilakukan adalah mengoptimasi sistem antrian dengan menggunakan distribusi poison dan distribusi eksponensial. 
Suatu proses kedatangan dalam suatu sistem antrian artinya menentukan distribusi probabilitas unntuk jumlah kedatangan untuk suatu periode waktu. Pada umumnya, suatu proses kedatangan terjadi secara acak dan independent terhadap proses kedatangan lainnya dan tidak dapat diprediksi kapan pelanggan akan datang. Dalam hal ini, distribusi probabilitas Poisson menyediakan deskripsi yang cukup baik untuk suatu pola kedatangan.

Suatu fungsi probabilitas Poisson untuk suatu kedatangan x pada suatu periode waktu. Sedangkan untuk Pola pelayanan ditentukan oleh waktu pelayanan yaitu waktu yang dibutuhkan untuk melayani pelanggan pada fasilitas pelayanan. Waktu pelayanan dapat berupa waktu pelayanan konstan ataupun variabel acak yang telah diketahui probabilitasnya. Tingkat pelayanan adalah jumlah pelanggan yang dilayani per satuan waktu. Dengan asumsi channel selalu dalam keadaan sibuk sehingga tidak ada waktu idle yang dialami oleh channel itu.

Beberapa penelitian sebelumnya yaitu model antrian pada system pembayaran di golden pasar swalayan Manado.[1] dan deskripsi tingkat kepuasan masyarakat terhadap pelayanan di Satuan Penyelenggara Adminstrasi Surat Izin mengemudi di Kepolisian Resor kota Manado menggunakan Regresi Logistik Ordinal.[2]

\section{ANTRIAN}

\subsection{Teori Antrian}

Teori Antrian (queuing theory) merupakan studi matematika dari antrian atau kejadian garis tunggu dari pelanggan yang memerlukan layanan dari sistem yang ada [1]. Sebuah organisasi harus berusaha memberikan pelayanan agar pelanggan tidak mengantri terlalu lama. Biasanya ada biaya bagi organisasi untuk menambah fasilitas layanan.Layanan yang cepat akan mempertahankan pelanggan dan jangka panjang meningkatkan keuntungan perusahaan.

Sebuah sistem antrian adalah suatu himpunan pelanggan, pelayan dan suatu antrian yang mengatur kedatangan pelanggan dan pemrosesan masalahnya. Pelanggan yang tiba dapat bersifat tetap atau tidak tetap untuk memperoleh pelayanan. Apabila pelanggan yang tiba dapat langsung masuk kedalam sistem pelayanan maka pelanggan tersebut langsung dilayani, sebaliknya jika harus menunggu maka mereka harus membentuk antrian hingga tiba waktu pelayanan [3].

Disiplin antrian adalah aturan dimana para pelanggan dilayani. Aturan pelayanan menurut urutan kedatangan dapat didasarkan pada:

1. Pertama Masuk Pertama Keluar atau First In First Out (FIFO),

2. Yang Terakhir Masuk Yang Pertama Keluar atau Last In First Out (LIFO),

3. Pelayanan Dalam Urutan Acak atau Service In Random Order (SIRO),

4. Pelayanan Berdasarkan Prioritas [3].

Elemen-elemen dasar model antrian bergantung pada faktor sebaran kedatangan, barisan antri, mekanisme pelayanan, waktu pelayanan, dan sumber pelayanan [3].

\subsection{Sistem Antrian}

Sistem antrian adalah kedatangan pelanggan untuk mendapatkan pelayanan. Fenomena menunggu adalah hasil langsung dari keacakan dalam operasi sarana pelayanan. Secara umum, kedatangan pelanggan dan waktu perbaikan tidak diketahui sebelumnya, karena jika dapat diketahui, pengoperasian sarana tersebut dapat dijadwalkan sedemikian rupa sehingga akan sepenuhnya menghilangkan keharusan untuk menunggu.

Dsistem antrian terdapat unit-unit yang memerlukan pelayanan menolak memasuki sistem antrian jika antrian itu terlalu panjang yang lebih dikenal dengan istilah balking.[4] Pelanggan yang tak sabar dan memutuskan untuk meninggalkan system sebelum dilayani dinamakan reneging.[5].

\subsection{Model Antrian}

Ada empat model struktur antrian dasar yang umum terjadi dalam seluruh sistem antrian:

1. Satu Jalur, Satu Tahap (Single Channel, Single Phase)

Sistem antrian satu jalur satu tahap berarti bahwa dalam sistem tersebut hanya terdapat satu pemberi layanan serta satu jenis layanan yang diberikan, sehingga yang telah menerima pelayanan dapat langsung keluar dari sistem antrian.

Sistem Antrian :

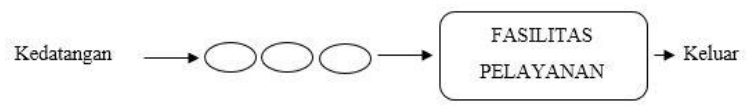

Gambar 1. Satu Jalur, Satu Tahap

2. Satu Jalur, Banyak Tahap (Single Channel, Multi Phase)

Sistem antrian satu saluran banyak tahap berarti dalam sistem antrian tersebut terdapat lebih dari satu jenis layanan yang diberikan, tetapi dalam setiap jenis layanan hanya terdapat satu pemberi layanan.

Sistem Antrian :

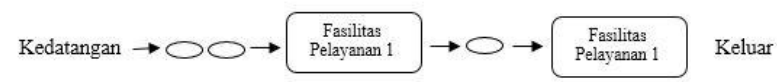

Gambar 2. Satu Jalur Banyak tahap

3. Banyak Jalur, Satu Tahap (Multi Channel, Single Phase)

Sistem antrian banyak saluran satu tahap adalah sistem antrian dimana terdapat satu jenis layanan dalam sistem antrian tersebut, namun terdapat lebih dari satu pemberi layanan.

Sistem Antrian :

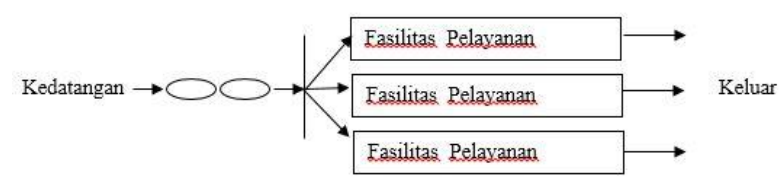

Gambar 3. Banyak Jalur, Satu Tahap

4. Banyak Jalur, Banyak Tahap (Multi Channel, Multi Phase) 
Sistem antrian banyak saluran banyak tahap adalah sistem antrian dimana terdapat lebih dari satu jenis layanan dan terdapat lebih dari satu pemberi layanan dalam setiap jenis layanan [3].

Sistem antrian :

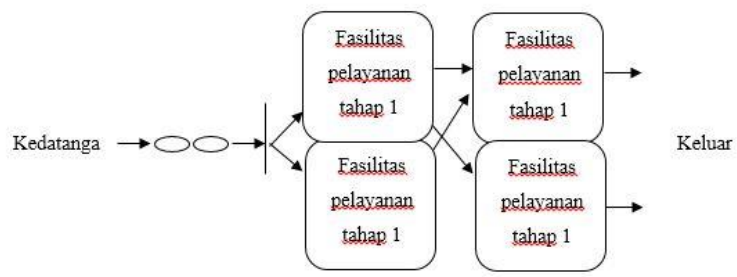

Gambar 4. Banyak Jalur, Banyak tahap

\subsection{Struktur Dasar Model Antrian}

Dari sudut pandang model antrian, situasi antrian dapat diciptakan dengan cara berikut ini. Sementara para pelanggan tiba di satu sarana pelayanan, mereka bergabung dalam sebuah antrian. Pelayan memilih seorang pelanggan dari antrian untuk memulai pelayanan. Setelah seleslainya pelayanan proses memilih pelanggan baru (yang sedang menunggu) diulangi. Diasumsikan tidak ada waktu yang terhilang antara penyelesaian pelayanan dengan diterimanya seorang pelanggan baru di sarana pelayanan tersebut [6s].

\subsection{Distribusi Poison}

Tingkat kedatangan pelanggan per interval waktu disimbolkan dengan $\lambda$. Maka $1 / \lambda$ menyatakan waktu rata-rata kedatangan pelanggan. Jumlah kedatangan per unit waktu pada suatu fasilitas pelayanan didefinisikan dengan Distribusi Poisson dengan rumus:

Dimana :

$$
\text { p_n }=\left(\lambda^{\wedge} n \mathrm{e}^{\wedge}(-\lambda)\right) / \mathrm{n} !, \quad \mathrm{n}=0,1,2, \ldots
$$

p_n : peluang terjadinya $\mathrm{n}$ per satuan waktu

$\mathrm{n} \quad$ : banyaknya pelanggan

$\lambda^{\wedge} \mathrm{n} \quad$ : rata-rata terjadinya $\mathrm{n}$ per satuan waktu

$\mathrm{e}^{\wedge}(-\lambda) \quad: \mathrm{e}(2,71828)$ dipangkatkan negatif lamda

\subsection{Distribusi Eksponensial}

Rata-rata pelayanan diberi simbol $\mu$ yang mana merupakan banyaknya pelanggan yang dapat dilayani dalam satuan (unit) waktu, sedangkan ratarata waktu pelayanan ialah rata-rata waktu yang dipergunakan untuk melayani per pelanggan yang diberi simbol $1 / \mu$ unit (satuan). Pola pelayanan yang mengikuti distribusi eksponensial dengan rumus:

$$
\mathrm{p}(\mathrm{t})=\llbracket \mu \mathrm{e} \rrbracket^{\wedge}(-\mu \mathrm{t}) ; \mathrm{t} \geq 0
$$

Dimana :

$\mathrm{p}(\mathrm{t}) \quad$ : peluang kejadian $\mathrm{n}$ selama waktu $\mathrm{t}$

$\mu \quad$ : rata-rata tingkat pelayanan (unit pelayanan per unit waktu)

e $: 2,71828$

\subsection{Pola Kedatangan dan Lama Pelayanan}

Fungsi peluang poisson digunakan untuk menggambarkan tingkat kedatangan dengan asumsi bahwa jumlah kedatangan adalah acak dan kedatangan pelanggan antar interval waktu saling tidak mempengaruhi. Peluang tepat terjadinya X kedatangan dalam sebaran poisson dapat diketahui dengan menggunakan rumus:

Dimana :

$$
P(x)=\frac{\lambda^{x} e^{-\lambda}}{x !}
$$

$P(x) \quad$ : Peluang bahwa ada $\mathrm{x}$ kedatangan dalam sistem.

$\lambda \quad$ : Tingkat kedatangan rata-rata.

$e \quad$ : Bilangan Navier $(\mathrm{e}=2,71828)$

$x \quad$ : Variabel acak diskrit yang menyatakan banyaknya kedatangan printerval waktu.

Sedangkan lama pelayanan mengikuti sebaran Eksponensial. Ini bisa dilakukan dengan membandingkan sampel waktu pelayanan yang sebenarnya dengan waktu pelayanan yang diharapkan berdasarkan rumus sebagai berikut:

$$
f(t)=\mu^{-\mu t}
$$

\subsection{Uji Kesesuaian Poisson}

Untuk menghitung nilai $\chi 2$ dari data pengamatan pada $\mathrm{h} \_(1,)$ h_(2,)sampai h_(5,)terlebih dahulu ditentukan nilai waktu pelayanan yang diharapkan dengan menggunakan rumus sebaran Poisson dan mengambil nilai $t=1$ pada rumus sebaran Poisson.

$$
\text { Untuk menentukan nilai } \chi 2 \text { maka digunakan }
$$
rumus:

$$
x^{2}=\sum_{i=1}^{k} \frac{\left(\lambda_{i}-\bar{\lambda}\right)}{\bar{\lambda}}
$$

Dimana :

$\lambda \_$i $\quad$ tingkat kedatangan rata-rata

$\lambda^{-} \quad$ : rata-rata tingkat kedatangan

K : banyaknya pengamatan

Kriteria keputusan dilakukan dengan terima rata-rata pelayanan bersebaran Poisson apabila $X^{\wedge} 2$ hitung $\leq X$ $\wedge^{2}$ tabel dalam hal lain keputusan ditolak.

Tabel 1. Kedatangan $(\lambda)$

\begin{tabular}{|c|c|}
\hline Jam & Kedatangan $(\lambda)$ \\
\hline $09.00-10.00$ & $\lambda_{1}$ \\
\hline $10.00-11.00$ & $\lambda_{2}$ \\
\hline $11.00-12.00$ & $\lambda_{3}$ \\
\hline $13.00-14.00$ & $\lambda_{4}$ \\
\hline $14.00-15.00$ & $\lambda_{5}$ \\
\hline
\end{tabular}

$$
\lambda=\left(\lambda \_1+\lambda \_2+\cdots \lambda \_5\right) / 5
$$

Tabel 2. Waktu Pelayanan $(\mu)$

\begin{tabular}{|c|c|}
\hline Jam & Kedatangan $(\mu)$ \\
\hline $09.00-10.00$ & $\mu_{1}$ \\
\hline $10.00-11.00$ & $\mu_{2}$ \\
\hline $11.00-12.00$ & $\mu_{3}$ \\
\hline $13.00-14.00$ & $\mu_{4}$ \\
\hline $14.00-15.00$ & $\mu_{5}$ \\
\hline \multicolumn{2}{|c|}{$\mu=\frac{\mu_{1}+\mu_{2}+\cdots \mu_{5}}{5}$} \\
\hline
\end{tabular}

- Rata-rata kedatangan hari senin $=\frac{1}{\lambda_{1}}$

- $\quad$ Rata-rata kedatangan hari selasa $=\frac{1}{\lambda_{2}}$

- $\quad$ Rata-rata kedatangan hari rabu $=\frac{1}{\lambda_{3}}$

- $\quad$ Rata-rata kedatangan hari kamis $=\frac{1}{\lambda_{4}}$ 
- $\quad$ Rata-rata kedatangan hari jumat $=\frac{1}{\lambda_{5}}$

- $\quad$ Rata-rata waktu pelayanan hari senin $=\frac{1}{\mu_{1}}$

- $\quad$ Rata-rata waktu pelayanan hari selasa $=\frac{1}{\mu_{2}}$

- $\quad$ Rata-rata waktu pelayanan hari rabu $=\frac{1}{\mu_{3}}$

- Rata-rata waktu pelayanan hari kamis (minggu pertama $)=\frac{1}{\mu_{4}}$

- Rata-rata waktu pelayanan hari jumat (minggu pertama $)=\frac{1}{\mu_{5}}$

Lama pelayanan yang dihitung sejak kedatangan pelanggan dalam sistem antrian sampai selesai pelayanan mengikuti sebaran Eksponensial. Ini bisa dilakukan dengan membandingkan sampel waktu pelayanan yang sebenarnya dengan waktu pelayanan yang diharapkan berdasarkan rumus sebagai berikut:

$$
f(t)=\mu^{\wedge}(-\mu t)
$$

Dimana :

$\mu$ : Rata-rata tiap pelayanan (unit pelayanan per unit waktu).

$e \quad$ : Bilangan Navier $e=2,71828$.

$t$ : Waktu lamanya pelayanan (unit pelayanan per unit waktu).

Suatu distribusi mengikuti pola distribusi poisson jika mengikuti aturan berikut :

a. Tidak terdapat dua kejadian yang terjadi bersamaan

b. Proses kedatangan bersifat acak

c. Rata-rata jumlah kedatangan per interval waktu sudah diketahui dari pengamatan sebelumnya.

d. Bila interval waktu dibagi ke dalam interval yang lebih kecil, maka pernyataan-pernyataan berikut ini harus dipenuhi :

- Probabilitas tepat satu kedatangan adalah kecil dan konstan.

- Probabilitas dua kedatangan atau lebih selama interval waktu tersebut angkanya sangat kecil sehingga mendekati nol.

- Jumlah kedatangan pada interval waktu tersebut tidak tergantung pada kedatangan di interval waktu sebelum dan sesudahnya.

\subsection{Uji Kesesuaian Eksponensial}

Untuk menghitung nilai $\chi^{2}$ dari data pengamatan pada, $h_{1}, h_{2}$, sampai $h_{5}$, terlebih dahulu ditentukan nilai waktu pelayanan yang diharapkan dengan menggunakan rumus

sebaran Eksponensial dan menggunakan $t=1$.

Untuk menentukan nilai $\chi 2$ maka digunakan rumus:

$$
X^{2}=\sum_{i=1}^{k} \frac{(\mu i-\mu i \text { harapan })^{2}}{\mu i}
$$

Dimana :

$\mu i \quad$ : Rata-rata waktu pelayanan pada waktu ke- i

$\mu$ harapan : Rata-rata waktu pelayanan harapan pada waktu ke - i

$k \quad$ : Banyaknya pengamatan

Kriteria keputusan dilakukan dengan terima rata-rata pelayanan bersebaran eksponensial apabila

$X^{2}$ hitung $\leq X^{2}{ }_{\text {tabel }}$ dalam hal lain keputusan ditolak.
Distribusi eksponensial memiliki ciri-ciri sebagai berikut :

a. Waktu antar kejadian bersifat acak.

b. Waktu antar kejadian berikutnya independen terhadap waktu antar kejadian sebelumnya.

c. Waktu pelayanan dalam antrian tergantung dari unit yang dilayani.

\section{METODOLOGI PENELITIAN}

\subsection{Waktu dan tempat Penelitian}

Pelaksanaan penelitian ini dilakukan di Satuan Penyelenggaraan Adminstrasi SIM Resort Kepolisian Manado. Pelaksanaan penelitian dilakukan selama 1 minggu yaitu dimulai tanggal 15-23 Mei 2017. Pengambilan data mulai dari pukul 09.00-15.00 WITA.

\subsection{Metode Penelitian}
1. Perumusan masalah
2. Pengumpulan data
3. Mencari solusi

\subsection{Populasi dan Sampel}

Populasi dari penelitian ini adalah pemohon SIM di Satuan Penyelenggaraan Adminstrasi SIM Resort Kepolisian Manado. Jumlah sampel dalam penelitian ini sebanyak 100 orang yang masuk dalam sistem antrian (Perpanjang SIM Motor).

\section{HASIL DAN PEMBAHASAN}

4.1. Pengumpulan Data

Tabel 3. Data tingkat kedatangan pemohon SIM (perpanjang) setiap jam

\begin{tabular}{|c|c|c|c|c|c|}
\hline Hari/Waktu & $\begin{array}{c}\text { Hari } \\
\left(h_{1}\right)\end{array}$ & $\begin{array}{c}\text { Hari } \\
\left(h_{2}\right)\end{array}$ & $\begin{array}{c}\text { Hari } \\
\left(h_{3}\right)\end{array}$ & $\begin{array}{c}\text { Hari } \\
\left(h_{4}\right)\end{array}$ & $\begin{array}{c}\text { Hari } \\
\left(h_{5}\right)\end{array}$ \\
\hline $09.00-10.00$ & 32 & 20 & 18 & 15 & 21 \\
\hline $10.00-11.00$ & 21 & 18 & 16 & 20 & 13 \\
\hline $11.00-12.00$ & 22 & 23 & 14 & 15 & 11 \\
\hline $13.00-14.00$ & 25 & 17 & 16 & 19 & 11 \\
\hline $14.00-15.00$ & 23 & 13 & 13 & 17 & 11 \\
\hline
\end{tabular}

Keterangan :

$\lambda\left(h_{1}\right)$ adalah tingkat kedatangan hari ke $\mathrm{i}$, dimana $\mathrm{i}=1$, $2,,, 5$

$\lambda$ menyatakan tingkat kedatangan maka dapat dicari sebagai berikut.

$\lambda$ untuk pemohon SIM :

$\lambda\left(h_{1}\right)=\frac{32+21+22+25+23}{5}=24.6$ pemohon $/ 6$ omenit

Dari hitungan yang sama maka diapat :

$\lambda\left(h_{2}\right)=18.2$ pemohon $/ 60$ menit

$\lambda\left(h_{3}\right)=15.4$ pemohom $/ 60$ menit

$\lambda\left(h_{4}\right)=17.2$ pemohon $/ 60$ menit

$\lambda\left(h_{5}\right)=13.4$ pemohon $/ 60$ menit

Tabel 4. Data rata - rata waktu pelayanan (dalam menit) pada loket I

\begin{tabular}{|c|c|c|c|c|c|}
\hline Hari/Waktu & $\begin{array}{c}\text { Hari } \\
\left(h_{1}\right)\end{array}$ & $\begin{array}{c}\text { Hari } \\
\left(h_{2}\right)\end{array}$ & $\begin{array}{c}\text { Hari } \\
\left(h_{3}\right)\end{array}$ & $\begin{array}{c}\text { Hari } \\
\left(h_{4}\right)\end{array}$ & $\begin{array}{c}\text { Hari } \\
\left(h_{5}\right)\end{array}$ \\
\hline $09.00-10.00$ & 1.7 & 1.25 & 1.43 & 1.33 & 1.35 \\
\hline $10.00-11.00$ & 1.6 & 1.40 & 1.29 & 1.29 & 1.27 \\
\hline $11.00-12.00$ & 1.7 & 1.6 & 1.36 & 1.25 & 1.26 \\
\hline $13.00-14.00$ & 1.9 & 1.38 & 1.37 & 1.36 & 1.23 \\
\hline $14.00-15.00$ & 1.9 & 1.41 & 1.33 & 1.29 & 1.30 \\
\hline
\end{tabular}

Menghitung rata-rata waktu pelayanan dengan menggunakan rumus : 


$$
\mu\left(h_{i}\right)=\frac{1}{\left(\frac{h_{1}+h_{2}+h_{3}+h_{4}+h_{5}}{n}\right)}
$$

Untuk menghitung nilai harapan untuk $t=1$, dengan rumus $F(t)=\mu e^{-\mu t}$.

Jadi didapatkan nilai rata-rata waktu pelayanan dan $\mu$ harapan seperti yang dlihat pada tabel 3 .

Tabel 5. Nilai rata-rata waktu pelayanan dan $\mu$ harapan pada loket I

\begin{tabular}{|c|c|c|}
\hline Hari & Rata-rata waktu pelayanan & $\mu_{\text {harapn }}$ \\
\hline$h_{1}$ & 0.568 & 0.321 \\
\hline$h_{2}$ & 0.711 & 0.349 \\
\hline$h_{3}$ & 0.737 & 0.352 \\
\hline$h_{4}$ & 0.766 & 0.356 \\
\hline$h_{5}$ & 0.780 & 0.357 \\
\hline
\end{tabular}

Tabel 6. Data rata - rata waktu pelayanan (dalam menit) untuk loket II

\begin{tabular}{|c|c|c|c|c|c|}
\hline $\begin{array}{c}\text { Hari/ } \\
\text { Waktu }\end{array}$ & $\begin{array}{c}\text { Hari } \\
\left(h_{1}\right)\end{array}$ & $\begin{array}{c}\text { Hari } \\
\left(h_{2}\right)\end{array}$ & $\begin{array}{c}\text { Hari } \\
\left(h_{3}\right)\end{array}$ & $\begin{array}{c}\text { Hari } \\
\left(h_{4}\right)\end{array}$ & $\begin{array}{c}\text { Hari } \\
\left(h_{5}\right)\end{array}$ \\
\hline $\begin{array}{c}0.9 .00- \\
10.00\end{array}$ & 1.599 & 1.411 & 1.236 & 1.352 & 1.48 \\
\hline $\begin{array}{c}10.00- \\
11.00\end{array}$ & 1.532 & 1.396 & 1.388 & 1.366 & 1.347 \\
\hline $\begin{array}{c}11.00- \\
12.00\end{array}$ & 1.265 & 1.532 & 1.827 & 1.802 & 1.307 \\
\hline $\begin{array}{c}13.00- \\
14.00\end{array}$ & 1.622 & 1.247 & 1.366 & 1.278 & 1.283 \\
\hline $\begin{array}{c}14.00- \\
15.00\end{array}$ & 1.556 & 1.477 & 1.666 & 1.628 & 1.676 \\
\hline
\end{tabular}

Berdasarkan persamaan 4.2, maka didapatkan nilai rata-rata waktu pelayanan dan $\mu$ harapan seperti yang dlihat pada tabel 7 .

Tabel 7. Nilai rata-rata waktu pelayanan dan $\mu$ harapan pada Loket II

\begin{tabular}{|c|c|c|}
\hline Hari & Rata-rata waktu pelayanan & $\mu_{\text {harapn }}$ \\
\hline$h_{1}$ & 0.660 & 0.341 \\
\hline$h_{2}$ & 0.708 & 0.348 \\
\hline$h_{3}$ & 0.668 & 0.342 \\
\hline$h_{4}$ & 0.673 & 0.343 \\
\hline$h_{5}$ & 0.705 & 0.348 \\
\hline
\end{tabular}

Tabel 8. Data rata - rata waktu pelayanan (dalam menit) untuk loket III

\begin{tabular}{|c|c|c|c|c|c|}
\hline Hari/Waktu & $\begin{array}{c}\text { Hari } \\
\left(h_{1}\right)\end{array}$ & $\begin{array}{c}\text { Hari } \\
\left(h_{2}\right)\end{array}$ & $\begin{array}{c}\text { Hari } \\
\left(h_{3}\right)\end{array}$ & $\begin{array}{c}\text { Hari } \\
\left(h_{4}\right)\end{array}$ & $\begin{array}{c}\text { Hari } \\
\left(h_{5}\right)\end{array}$ \\
\hline $09.00-10.00$ & 2.502 & 2.528 & 2.47 & 2.44 & 2.388 \\
\hline $10.00-11.00$ & 2.4 & 2.365 & 2.368 & 2.716 & 2.272 \\
\hline $1.00-12.00$ & 2.433 & 2.468 & 2.357 & 2.293 & 2.393 \\
\hline $13.00-14.00$ & 2.395 & 2.418 & 2.41 & 2.322 & 2.445 \\
\hline $14.00-15.00$ & 2.357 & 2.444 & 2.306 & 2.213 & 2.282 \\
\hline
\end{tabular}

Berdasarkan persamaan 4.2, maka didapatkan nilai rata-rata waktu pelayanan dan $\mu$ harapan seperti yang dlihat pada tabel 9.

Tabel 9. Nilai rata-rata waktu pelayanan dan $\mu$ harapan pada Loket II

\begin{tabular}{|c|c|c|}
\hline Hari & Rata-rata waktu pelayanan & $\mu_{\text {harapn }}$ \\
\hline$h_{1}$ & 0.413 & 0.273 \\
\hline$h_{2}$ & 0.409 & 0.271 \\
\hline$h_{3}$ & 0.419 & 0.276 \\
\hline$h_{4}$ & 0.417 & 0.274 \\
\hline$h_{5}$ & 0.424 & 0.277 \\
\hline
\end{tabular}

\subsection{Model Antrian}

Model antrian yang digunakan dalam penelitian ini adalah menggunakan model Singele Chanel Multi Pahse atau satu jalur banyak tahap.

\section{PENGOLAHAN DATA}

\subsection{Waktu Antar Kedatangan Pemohon SIM}

\subsubsection{Uji Kesesuaian Poisson}

Untuk menghitung nilai $\chi^{2}$ dari data pengamatan pada $h_{1}, h_{2}$, sampai $h_{5}$, terlebih dahulu ditentukan nilai waktu kedatangan yang diharapkan dengan menggunakan rumus sebaran Poisson dan mengambil nilai $t=1$ pada rumus sebaran Poisson.

Untuk menentukan nilai $\chi 2$ maka digunakan rumus:

$$
\chi^{2}=\sum_{i=1}^{k} \frac{\left(\lambda_{i}-\bar{\lambda}\right)}{\bar{\lambda}}
$$

Dimana :

$$
\begin{array}{ll}
\lambda_{i} & \text { : tingkat kedatangan rata-rata } \\
\bar{\lambda} & \text { : rata-rata tingkat kedatangan } \\
\mathrm{K} & \text { : banyaknya pengamatan }
\end{array}
$$

Untuk menghitung nilai $\chi 2$ dari data pengamatan pada $h_{1}, h_{2}$, sampai $h_{5}$, dihitung dengan menggunakan nilai tingkat kedatangan, dengan hipotesis :

$H_{1}$ : Kedatangan mengikuti sebaran poisson

$H_{0}$ : Kedatangan tidak mengikuti sebaran poisson

Kriteria keputusan dilakukan dengan terima ratarata kedatangan bersebaran Poisson apabila $\chi^{2}$ hitung $\leq \chi_{\text {tabel }}^{2}$ dalam hal lain keputusan ditolak.

Berdasarkan tabel 1, maka untuk menghitung rata-rata kecepatan kedatangan pemohon SIM digunakan persamaan :

$$
\frac{\lambda\left(h_{i}\right)}{60 \text { menit X interval waktu kedatanga }}=\frac{\lambda\left(h_{i}\right)}{300}
$$

Sehingga di dapat nilai rata-rata kecepatan kedatangan pemohon SIM pada tabel 10.

Tabel 1o. Rata - rata kecepatan kedatangan pemohon SIM

\begin{tabular}{|c|c|c|c|c|c|}
\hline Hari & $\left(h_{1}\right)$ & $\left(h_{2}\right)$ & $\left(h_{3}\right)$ & $\left(h_{4}\right)$ & $\left(h_{5}\right)$ \\
\hline$\lambda$ & 0.082 & 0.060 & 0.051 & 0.057 & 0.044 \\
\hline
\end{tabular}

Dari hasil rata - rata tingkat kedatangan perhari pada tabel 10 diatas dapat dilihat bahwa tingkat kedatangan yang paling kecil terdapat pada hari ke $5\left(h_{5}\right)$ yaitu sebesar 0.044 orang per menit. Dan untuk tingkat kedatangan terbesar terdapat pada hari ke $1\left(h_{1}\right)$ yaitu sebesar 0.082 orang per menit.

Dari data pada tabel 10 maka :

$\chi^{2}=\sum \frac{\left(\lambda_{i}-\bar{\lambda}\right)^{2}}{\bar{\lambda}}=\frac{0.000826}{0.058}=0.014$

Berdasarkan nilai batas kritis $\chi^{2}$ dengan taraf nyata $\alpha=$ 0.05 dan $k=5$, maka :

$\chi^{2}(1-\alpha)(k-1)=\chi^{2} 0.95(4)=0.711$

Sehingga $\chi_{\text {hitung }}^{2} \leq \chi_{\text {tabel }}^{2}$ yaitu $0.014 \leq 0.711$

Maka diterima asumsi bahwa pola kedatangan berdistribusi poisson. 
Dari asumsi diatas dapat disimpulkan bahwa pola kedatangan di SATPAS POLRESTA MANADO sesuai dengan yang diharapakan.

\section{WAKTU PELAYANAN PEMOHON SIM 6.1. Uji Kesesuaian Eksponensial}

Untuk menghitung nilai $\chi^{2}$ dari data pengamatan pada, $h_{1}, h_{2}$, sampai $h_{5}$, terlebih dahulu ditentukan nilai waktu pelayanan yang diharapkan dengan menggunakan rumus

sebaran Eksponensial dan menggunakan $t=1$.

Untuk menentukan nilai $\chi^{2}$ maka digunakan rumus:

$$
\chi^{2}=\sum_{i=1}^{k} \frac{\left(\mu_{i}-\mu_{\text {harapan }}\right)^{2}}{\mu_{i}}
$$

Untuk menghitung nilai $\chi^{2}$ dari data pengamatan pada, $h_{1}, h_{2}$, sampai $h_{5}$, terlebih dahulu ditentukan nilai waktu pelayanan yang diharapkan dengan menggunakan rumus sebaran Eksponensial dan menggunakan $t=1$.

Untuk menentukan nilai $\chi^{2}$ maka digunakan rumus:

$$
\chi^{2}=\sum_{i=1}^{k} \frac{\left(\mu_{i}-\mu_{\text {harapan }}\right)^{2}}{\mu_{i}}
$$

Tabel 11. Rata - rata kecepatan pelayanan pemohon SIM pada loket I berdasarkan tabel 3 .

\begin{tabular}{|c|c|c|c|c|c|}
\hline Hari & $h_{1}$ & $h_{2}$ & $h_{3}$ & $h_{4}$ & $h_{5}$ \\
\hline$\mu_{i}$ & 0.568 & 0.711 & 0.737 & 0.766 & 0.780 \\
\hline$\mu_{\text {harapan }}$ & 0.321 & 0.349 & 0.352 & 0.356 & 0.357 \\
\hline
\end{tabular}

Dari data diatas maka diperoleh :

$\chi^{2}=\sum_{i=1}^{k} \frac{\left(\mu_{i}-\mu_{\text {harapan }}\right)^{2}}{\mu_{i}}=\frac{0.687}{0.347}=1.979$

Berdasarkan nilai batas kritis $\chi^{2}$ dengan taraf nyata $\alpha=$ 0.05 dan $k=5$

Maka $\chi^{2}(1-\alpha)(k-1)=\chi^{2}(0.95)(4)=0.711$

Sehingga, $\chi_{\text {nitung }}^{2}>\chi_{\text {tabel }}^{2}$ yaitu $1.979>0.711$

Maka ditolak asumsi bahwa pola pelayanan pemohon SIM di loket I berdistribusi eksponensial.

Tabel 12. Rata - rata kecepatan pelayanan pemohon SIM di loket II berdasarkan tabel 5 .

\begin{tabular}{|c|c|c|c|c|c|}
\hline Hari & $\left(h_{1}\right)$ & $\left(h_{2}\right)$ & $\left(h_{3}\right)$ & $\left(h_{4}\right)$ & $\left(h_{5}\right)$ \\
\hline$\mu$ & 0.660 & 0.708 & 0.668 & 0.673 & 0.705 \\
\hline$\mu_{\text {harapan }}$ & 0.341 & 0.348 & 0.342 & 0.343 & 0.348 \\
\hline \multicolumn{7}{c}{$\chi^{2}=\sum_{i=1}^{k} \frac{\left(\mu_{i}-\mu_{\text {harapan }}\right)^{2}}{\mu_{i}}=\frac{0.573}{0.344}=1.665$}
\end{tabular}

Berdasarkan nilai batas kritis $\chi^{2}$ dengan taraf nyata $\alpha=0.05$ dan $k=5$

Maka $\chi^{2}(1-\alpha)(k-1)=\chi^{2} 0.95(4)=0.711$

Sehingga $\chi_{\text {hitung }}^{2}>\chi_{\text {tabel }}^{2}$ yaitu $1.665>0.711$

Maka ditolak asumsi bahwa pola pelayanan pemohon SIM di loket II berdistrubusi eksponensial

Tabel 13. Rata - rata kecepatan pelayanan pemohon SIM di loket III berdasarkan tabel 7

\begin{tabular}{c|c|c|c|c|c|}
\hline Hari & $h_{1}$ & $h_{2}$ & $h_{3}$ & $h_{4}$ & $h_{5}$ \\
\hline$\mu$ & 0.413 & 0.409 & 0.419 & 0.417 & 0.424 \\
\hline$\mu_{\text {harapan }}$ & 0.273 & 0.271 & 0.276 & 0.274 & 0.277 \\
$\chi^{2}=\sum_{i=1}^{k} \frac{\left(\mu_{i}-\mu_{\text {harapan }}\right)^{2}}{\mu_{i}}=\frac{0.101}{0.274}=0.368$
\end{tabular}

Berdasarkan nilai batas kritis $\chi^{2}$ dengan taraf nyata $\alpha=0.05$ dan $k=5$
Maka $\chi^{2}(1-\alpha)(k-1)=\chi^{2} 0.95(4)=0.711$ Sehingga, $\chi_{\text {nitung }}^{2}>\chi_{\text {tabel }}^{2}$ yaitu $0.368 \leq 0.711$

Maka diterima asumsi bahwa pola pelayanan pemohon SIM di Loket III berdistribusi eksponensial.

Dari asusmi diatas dapat disimpulkan bahwa pertama pada loket I dan II pola pelayanan nya tidak berdistribusi eksponensial atau tidak bersebaran eksponensial yang artinya pelayanan yang terjadi di SATPAS MANADO tidak sesuai dengan yang diaharapkan.

\section{KESIMPULAN}

Dari hasil pembahasan yang telah dilakukan maka dapat disimpulkan bahwa sistem antrian pada SATPAS POLRESTA Manado memiliki tingkat kedatangan pemohon SIM sebesar 0.014 orang per menit. Waktu pelayanan pemohon SIM di loket I 1.979 menit rata-rata pemohon SIM dilayani, dan waktu pelayanan pemohon SIM di loket II 1.665 menit rata-rata pemohon SIM dilayani, namun waktu pelayanan pemohon SIM di loket III 0.368 menit rata-rata pemohon SIM dilayani.

Dari hasil kesimpulan diatas maka pola kedatangan berdistribusi poisson yang artinya sesuai dengan harapan atau dengan kata lain antrian pada saat kedatngan sudah optimal. Pala pelayanan yang terjadi pada tempat pendaftaran (Loket I) dan tempat pengisian formulir (Loket II) tidak berdistribusi eksponensial, yang artinya, waktu pelayanan tidak sesuai dengan waktu yang diharapkan. Sedangkan pada tempat pengambilan SIM (Loket III) waktu pelayanan berdistribusi eksponensial yang artinya, waktu pelayanan sesuai dengan waktu yang diharapkan.

\section{REFERENSI}

[1] Sumarno M., Y. Langi., dan L. Latumakulita. 2015. Model Antrian pada Sistem Pembayaran di Golden Pasar Swalayan Manado. Jurnal de Cartesian. 4(2) : 180-187.

[2] Biri, P.V. , C. Mongi., dan M. Mananohas. 2017. deskripsi tingkat kepuasan masyarakat terhadap pelayanan di Satuan Penyelenggara Adminstrasi Surat Izin mengemudi di Kepolisian Resor kota Manado menggunakan Regresi Logistik Ordinal. Jurnal Ilmiah Sains. 17(2) : 100-107.

[3] Hilier L. 2008. Introduction to Operations Research, jilid 2. Penerbit Andi. Yogyakarta.

[4] Dimyati. 1999. Sistem Antrian. Jakarta.

[5] Mulyono, S. 2007. Rist Operasi Lembaga Penerbit Fakultas Ekonomi-UI. Jakarta.

[6] Kakiay, T. J. 2004. Dasar Teori Antrian untuk Kehidupan Nyata. Penerbit Andi. Yogyakarta.

[7] Taha, H. A. 1996. Riset Operasi, Suatu Pengantar, jilid 2. Binarupa Aksara. Jakarta.

[8] Bronson, R dan Hans, J. 1988. Teori dan Soal-Soal Operation Research, seri buku Schaum's. Erlangga. Jakarta.

[9] Ardhya, B. N.2007. Pelayanan Nasabah Pada PT. Bank X Cabang Menteng dengan Menggunakan Metode Sistem Antrian (Studi Kasus di PT. Bank X CabangMenteng). 
http://docs.google.com/viewer?url=http://eprin ts.ui.ac.id/742799/128253T+19260++Pelayanan + nasabah.f\&chrome=true[26Jan2011. 11.20 pm].

[10] Farkhan.2013. Aplikasi Teori Antrian dan Simulasi pada Pelayanan Teller Bank. Journal.unnes.ac.id.2:18-19.

[11] Hilier L. 2008. Introduction to Operations Research, jilid 2. Penerbit Andi. Yogyakarta.

[12] Kakiay, T.J. 2004. Dasar Teori Antrian untuk Kehidupan Nyata. Yogyakarta: Andi

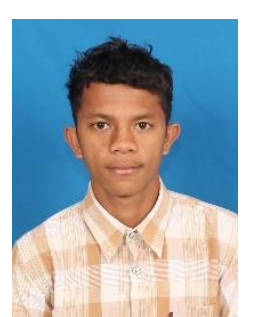

M. Safril Bahar lahir dan tinggal di Lifofa, Kecamatan Oba Selatan, Tidore. Dia masih menempuh pendidikan tinggi Program Studi Matematika dan Ilmu Pengetahuan Alam Universitas Sam Ratulangi Manado. Tahun 2018 adalah tahun terakhir ia menempuh studi. Makalah ini merupakan hasil penelitian skripsinya yang di publikasikan.

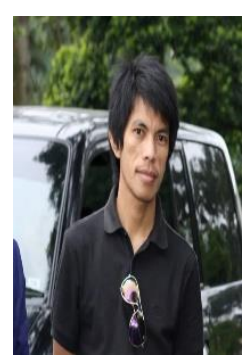

\section{Mans Mananohas}

(mansmananohas@yahoo.com) lahir di Salurang, Sulawesi Utara, Indonesia dan tinggal di Manado. Gelar Sarjana Sains (S.Si) diperolehnya dari Universitas Sam Ratulangi Manado pada tahun2006. Pada tahun 2013 ia menyelesaikan gelar Magister Sains (M.Si) di Institut Teknologi Bandung. Ia bekerja di UNSRAT sejak tahun $2008 \mathrm{di}$ Program Studi Matematika UNSRAT sebagai pengajar akademik (Dosen). Saat ini ia menjadi pengajar akademik tetap di UNSRAT.

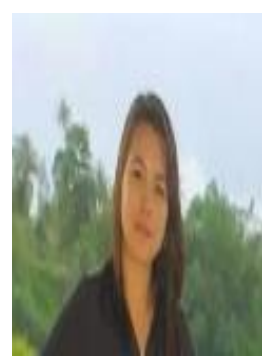

\section{Chriestie E.J.C Montolalu}

(chriestelly@yahoo.com) lahir pada tanggal 10 Desember 1985. Pada tahun 2007, gelar Sarjana Sains (S.Si) diperoleh dari Universitas Sam Ratulangi Manado. Gelar Master of Science (M.Sc) diperoleh dari Universitas of Queensland Australia pada tahun 2015. Ia bekerja di UNSRAT di Program Studi Matematika UNSRAT sebagai pengajar akademik (Dosen). Saat ini ia menjadi pengajar akademik tetap di UNSRAT. 